\title{
Utility of aeromagnetic studies for mapping of potentially active faults in two forearc basins: Puget Sound, Washington, and Cook Inlet, Alaska
}

\author{
R. W. Saltus ${ }^{1}$, R. J. Blakely ${ }^{2}$, P. J. Haeussler ${ }^{3}$, and R. E. Wells ${ }^{4}$ \\ ${ }^{1}$ U.S. Geological Survey, Mail Stop 964, Denver, CO 80225-0046, USA \\ ${ }^{2}$ U.S. Geological Survey, Mail Stop 989, 345 Middlefield Road, Menlo Park, CA 94025, USA \\ ${ }^{3}$ U.S. Geological Survey, 4200 University Drive, Anchorage, AK 99508, USA \\ ${ }^{4}$ U.S. Geological Survey, Mail Stop 973, 345 Middlefield Road, Menlo Park, CA 94025, USA
}

(Received January 30, 2004; Revised October 27, 2004; Accepted October 27, 2004)

\begin{abstract}
High-resolution aeromagnetic surveys over forearc basins can detect faults and folds in weakly magnetized sediments, thus providing geologic constraints on tectonic evolution and improved understanding of seismic hazards in convergent-margin settings. Puget Sound, Washington, and Cook Inlet, Alaska, provide two case histories. In each lowland region, shallow-source magnetic anomalies are related to active folds and/or faults. Mapping these structures is critical for understanding seismic hazards that face the urban regions of Seattle, Washington, and Anchorage, Alaska. Similarities in aeromagnetic anomaly patterns and magnetic stratigraphy between the two regions suggest that we can expect the aeromagnetic method to yield useful structural information that may contribute to earth-hazard and energy resource investigations in other forearc basins.
\end{abstract}

Key words: Aeromagnetic, susceptibility, seismic hazards.

\section{Introduction}

The populated lowlands of Puget Sound, Washington, and Cook Inlet, Alaska, lie within seismically active forearc basins in a dynamic convergent margin (Fig. 1). The Puget Lowland is home to some 3 million people and hosts the major cities of Seattle, Everett, Bellingham, Olympia, and Tacoma, Washington; and Vancouver and Victoria, British Columbia. The Puget Sound region has extensive urban infrastructure and includes a relatively large population density at low elevation and near shorelines. Cook Inlet has a lower total population (approximately 500 thousand), but hosts Alaska's largest city, Anchorage, and has extensive transportation and energy infrastructure of national importance.

Puget Sound lies within the forearc of the Cascadia subduction zone above the obliquely subducting Juan de Fuca plate and is adjacent to the Cascade volcanic arc. The lowland is underlain by several large sedimentary basins, including the Bellingham, Everett, Seattle and Tacoma basins, in some places reaching depths of 9 to $10 \mathrm{~km}$ (Brocher et al., 2001). Cook Inlet is a forearc basin situated above the subducting Pacific Plate and lying adjacent to the Aleutian volcanic arc. The Cook Inlet sedimentary basin has a maximum depth of about $5 \mathrm{~km}$ (Kirschner and Lyon, 1973).

Three kinds of earthquakes threaten Puget Sound and Cook Inlet. The megathrust contact between the subducting oceanic slab and overriding continental plate generates the world's greatest earthquakes, with recurrence intervals on the order of hundreds of years (Hyndman and Wang, 1995;

Published by TERRAPUB for The Society of Geomagnetism and Earth, Planetary and Space Sciences (SGEPSS), The Seismological Society of Japan, The Volcanological Society of Japan, The Geodetic Society of Japan, and The Japanese Society for Planetary Sciences.
Combellick, 1991, 1993, 1994). The 1964 M 9.2 Prince William Sound earthquake near Cook Inlet (Plafker, 1965; Christensen and Beck, 1994) and the 1700 Mw 9 Cascadia event near Puget Sound (Atwater and Hemphill-Haley, 1997) were both megathrust events. Puget Sound and Cook Inlet are also susceptible to deep intra-slab earthquakes $\geq$ M 7, which occur within the subducting slab at depths of 40-70 km, directly beneath the lowlands and its urban centers (Kirby et al., 1996). The Mw 6.8 Nisqually earthquake occurred at a depth of $57 \mathrm{~km}$ and caused an estimated \$2 billion in damage to the Puget Sound region in 2001 (Frankel et al., 2002). Estimated recurrence of damaging within-slab events is about 30-50 years in Puget Sound.

More infrequent, but potentially much more damaging, are shallow earthquakes that occur along crustal faults in the overriding continental plate. The city of Kobe, Japan, which occupies a similar forearc tectonic setting to Anchorage and Seattle, was devastated by the $1995 \mathrm{Mw} 6.9$ Hyogoken Nanbu earthquake. The Hyogo-ken Nanbu earthquake, which occurred on a shallow crustal fault, caused the loss of more than 5000 lives and $\$ 100$ billion in damage. Paleoseismic evidence indicates the Seattle fault, which lies beneath the cities of Seattle, Bremerton, and Bellevue, generated a M 7 earthquake about 1100 years ago (Bucknam et al., 1992; Nelson et al., 2003).

Finding the crustal faults beneath the major population centers of the Puget Sound and Cook Inlet-and understanding their location, geometry, and seismic hazard is critical in mitigating the effects of large crustal earthquakes. However, many of the faults are concealed beneath Quaternary sediments, vegetation, water, and urban development, so that geophysical methods are essential to accurately map their extent. Aeromagnetic surveys have proven especially 


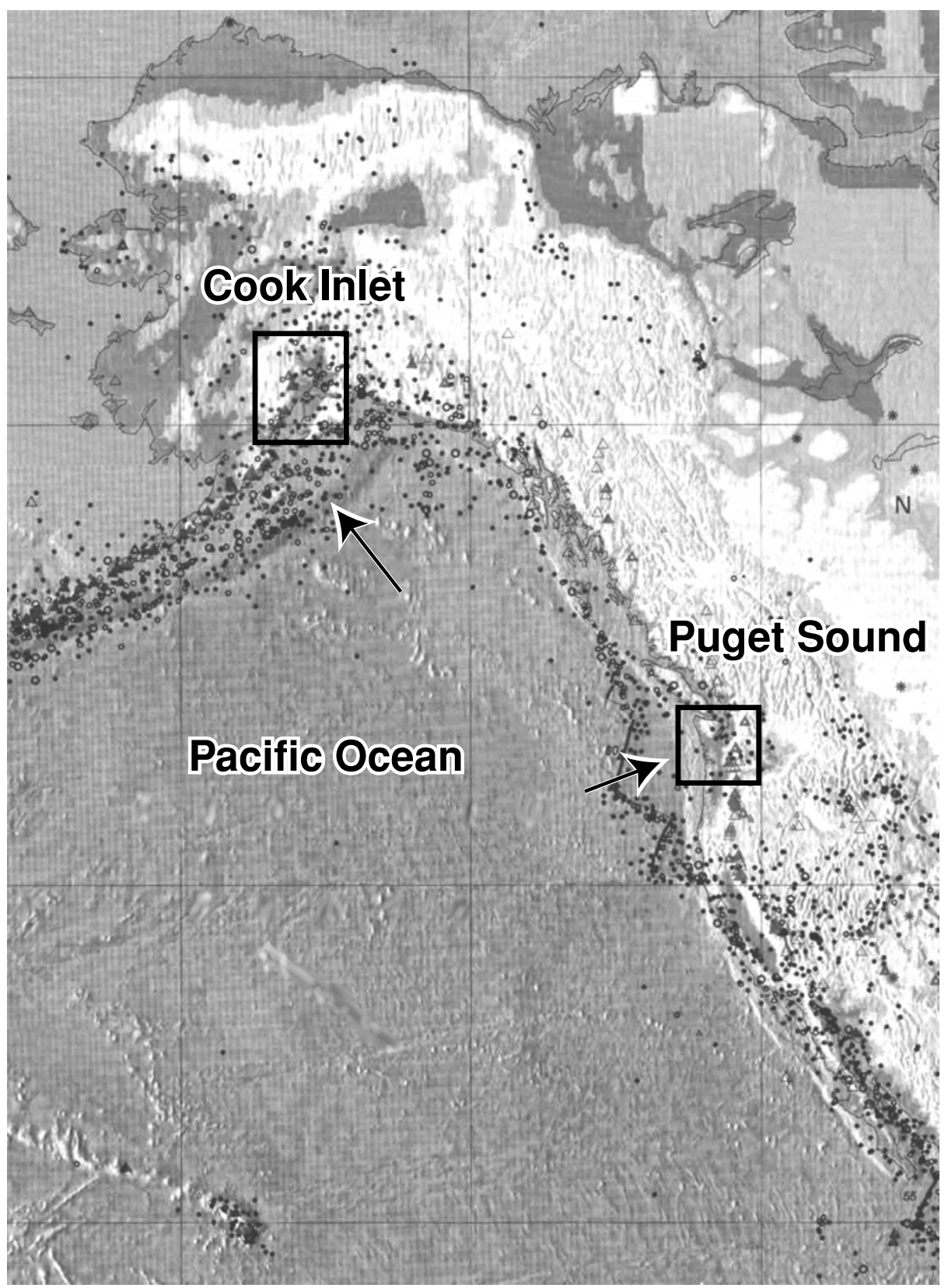

Fig. 1. Topography and bathymetry of northwestern North America and the Pacific Ocean, showing location of Puget Sound and Cook Inlet study areas. Circles show major earthquake locations, triangles show major volcanoes. The arrows depict the approximate direction of tectonic plate convergence with respect to North America in each region.

valuable in recognizing shallow crustal structures in both the Puget Lowland and in Cook Inlet (e.g., Blakely et al., 1999, 2002, 2004; Saltus et al., 2001).

In this paper we make a comparative examination of aeromagnetic data from Puget Sound and Cook Inlet and find remarkable similarities in aeromagnetic anomalies measured in both regions. The large-scale crustal structure in both regions is well defined by aeromagnetic anomalies that outline fault-bounded crustal blocks, but filtering of the high resolution data shows that subtle, near-surface anomalies are also recognizable. Structures imaged in this way are proving useful for interpreting young deformation features and potentially active faults and folds.

\section{Geology \\ 2.1 Puget Sound}

The Puget Lowland occupies the structural depression between the Olympic Mountains and Coast Range to the west and the Cascade volcanic arc to the east (Fig. 2). Much of the western part of the Lowland is underlain by Eocene Crescent Formation of largely basalt composition and oceanic affinity. These massive rocks crop out in the Olympic Mountains and dip shallowly eastward beneath the Puget Sound. Amalgamated pre-Tertiary, ophiolite-bearing oceanic terranes and overlying Tertiary Cascade volcanic rocks underlie the Lowland to the north and east and form the high topography of the Cascade Range. All of these bedrock units produce high-amplitude magnetic anomalies. A number of regionally significant thrust, strike-slip, and 


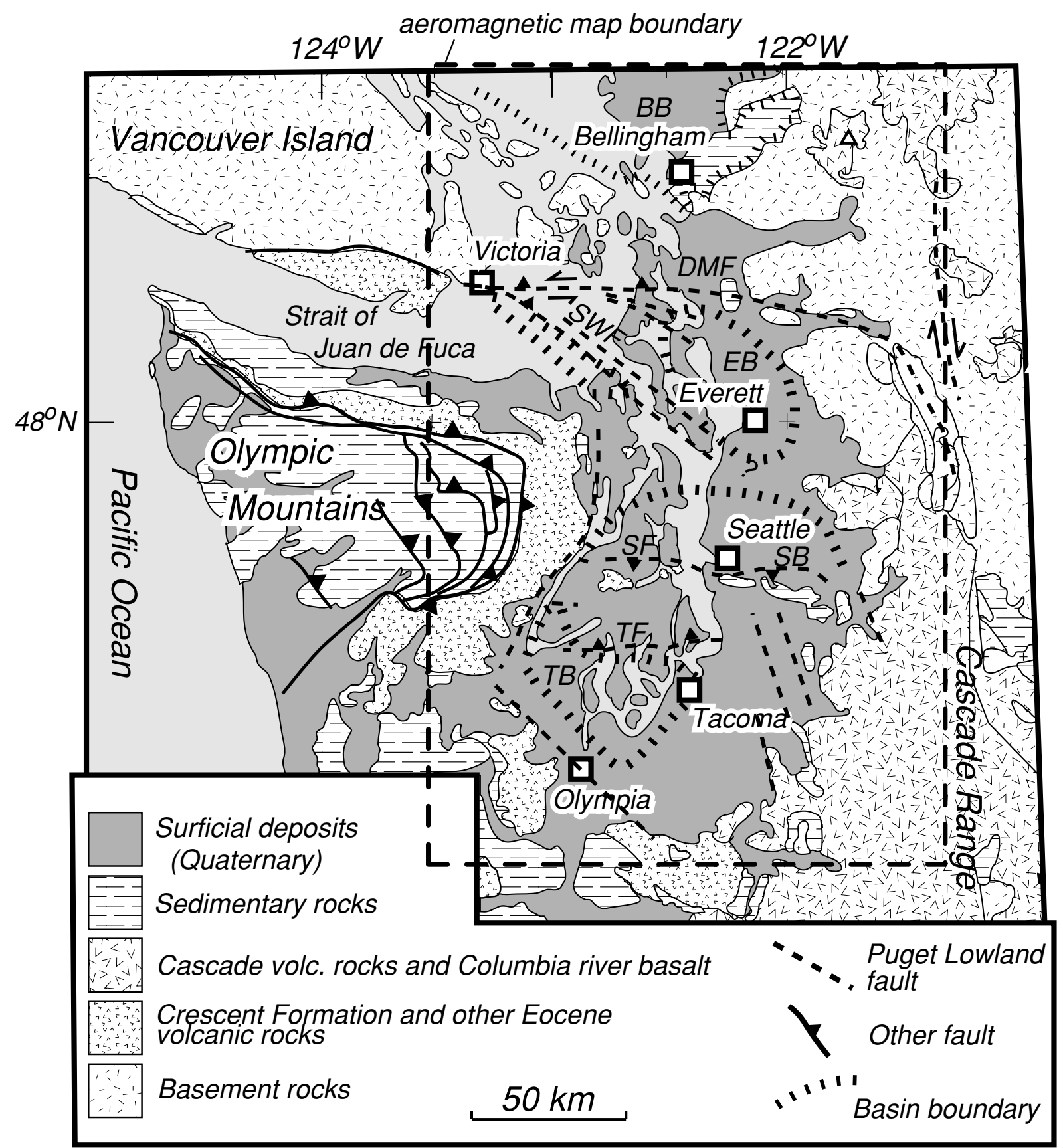

Fig. 2. Generalized geology of the Puget Sound region, modified from Johnson et al. (1996). Abbreviations: SF, Seattle fault; DMF; Devils Mountain fault; SWF, southern Whidbey Island fault; TF, Tacoma fault; BB, Bellingham basin; EB, Everett basin; SB, Seattle basin; TB, Tacoma basin.

oblique faults are superimposed on this bedrock framework, including the Devils Mountain, southern Whidbey Island, Seattle, and Tacoma faults (Fig. 2). These faults form the structural boundaries between important sedimentary basins that line up along the Puget Lowland, notably the Bellingham, Everett, Seattle, and Tacoma basins (Fig. 2). Geophysical studies (Brocher et al., 2001; Johnson et al., 1996) indicate that the Seattle and Everett basins exceed 6 and $9 \mathrm{~km}$ depth, respectively. Eocene and younger sediments that fill these basins were derived, in part, from ancient volcanic highlands, and shallow portions of these sedimentary sections produce low-amplitude anomalies where the sediments have been deformed into complex structures. The bedrock geology, regional faults, and sedimen- tary basins are largely obscured by the cover of Quaternary glacial and fluvial deposits, vegetation, and the deep waters of Puget Sound.

\subsection{Cook Inlet}

The Cook Inlet basin lies between the Kenai Mountains to the southeast and the southern Alaska Range and northern Aleutian Range to the north and west (Fig. 3). Triassic (?) to Lower Jurassic metavolcanic, ultramafic, and volcaniclastic rocks of the magnetic Talkeetna Formation are thought to underlie the entire basin. The Border Ranges fault (BRF) parallels the southeast margin of the basin and marks a transition to the non-magnetic, accretionary metavolcanic slate and greywacke mélange of the McHugh Complex and Valdez Group in the Kenai and 


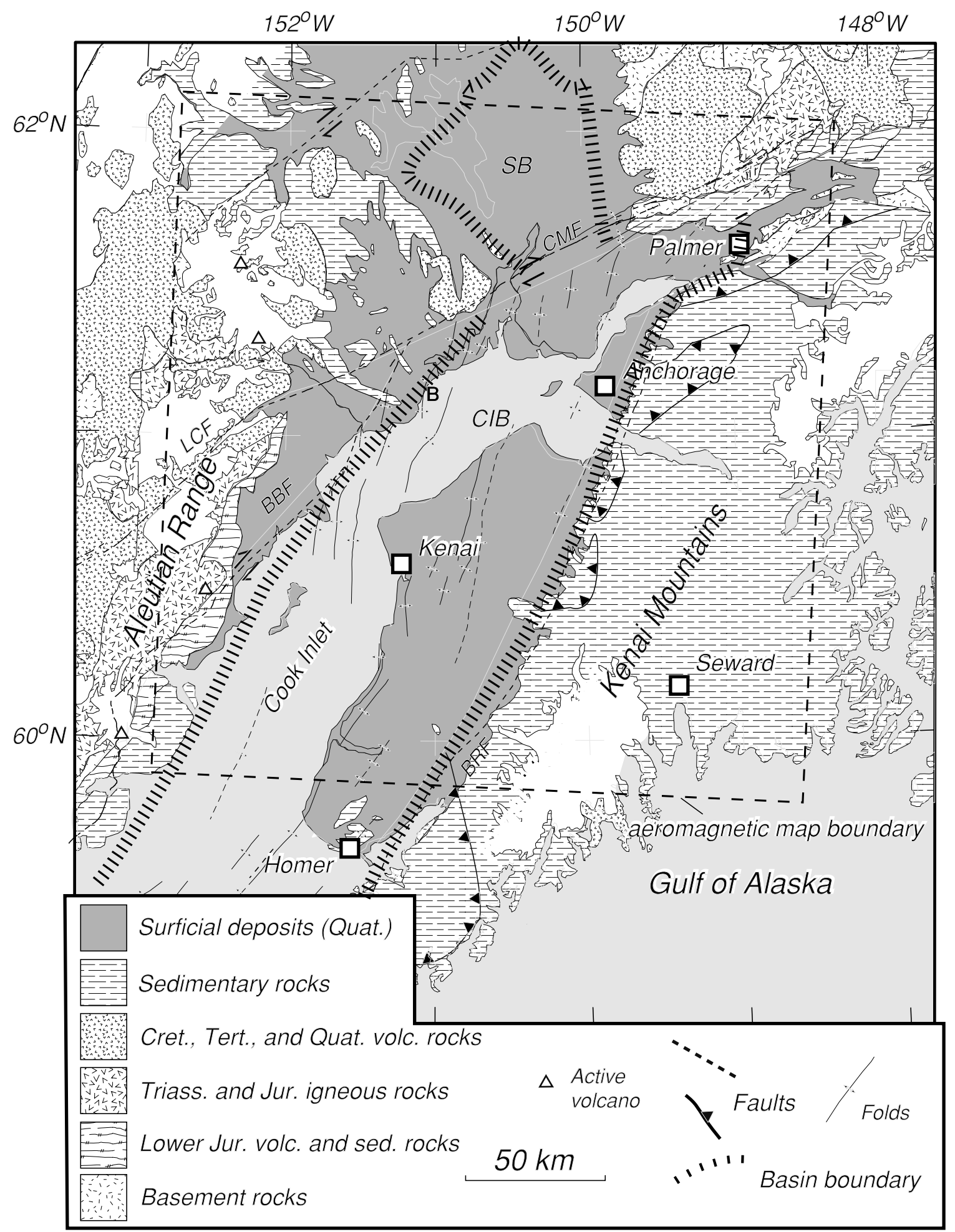

Fig. 3. Generalized geology of the Cook Inlet region, based on Magoon et al. (1976); folds from Haeussler and Saltus (in review (a)). Abbreviations: BBF, Bruin Bay fault; BRF, Border Ranges fault; CMF, Castle Mountain fault; LCF, Lake Clark fault; CIB, Cook Inlet Basin; SB, Susitna Basin; B, Beluga oil and gas field.

Chugach Mountains. The northernmost volcanoes of the active Aleutian volcanic arc and associated volcanic rocks lie northwest of the basin. Within this forearc tectonic framework, the Cook Inlet basin is separated from the Susitna basin to the north by the Castle Mountain fault, and from the Shelikof basin to the southwest by the Seldovia arch. Within the Cook Inlet basin, the Miocene and later sedi- ments are derived, in part, from magnetic rocks in the highlands to the north and west. Shallow magnetic intervals of these sedimentary rocks produce low-amplitude aeromagnetic anomalies where they have been deformed by later fault-cored folds (Haeussler et al., 2000). Many of these folds host oil and/or gas accumulations (Kirshner and Lyon, 1973; Magoon et al., 1976). At least some of the folds 


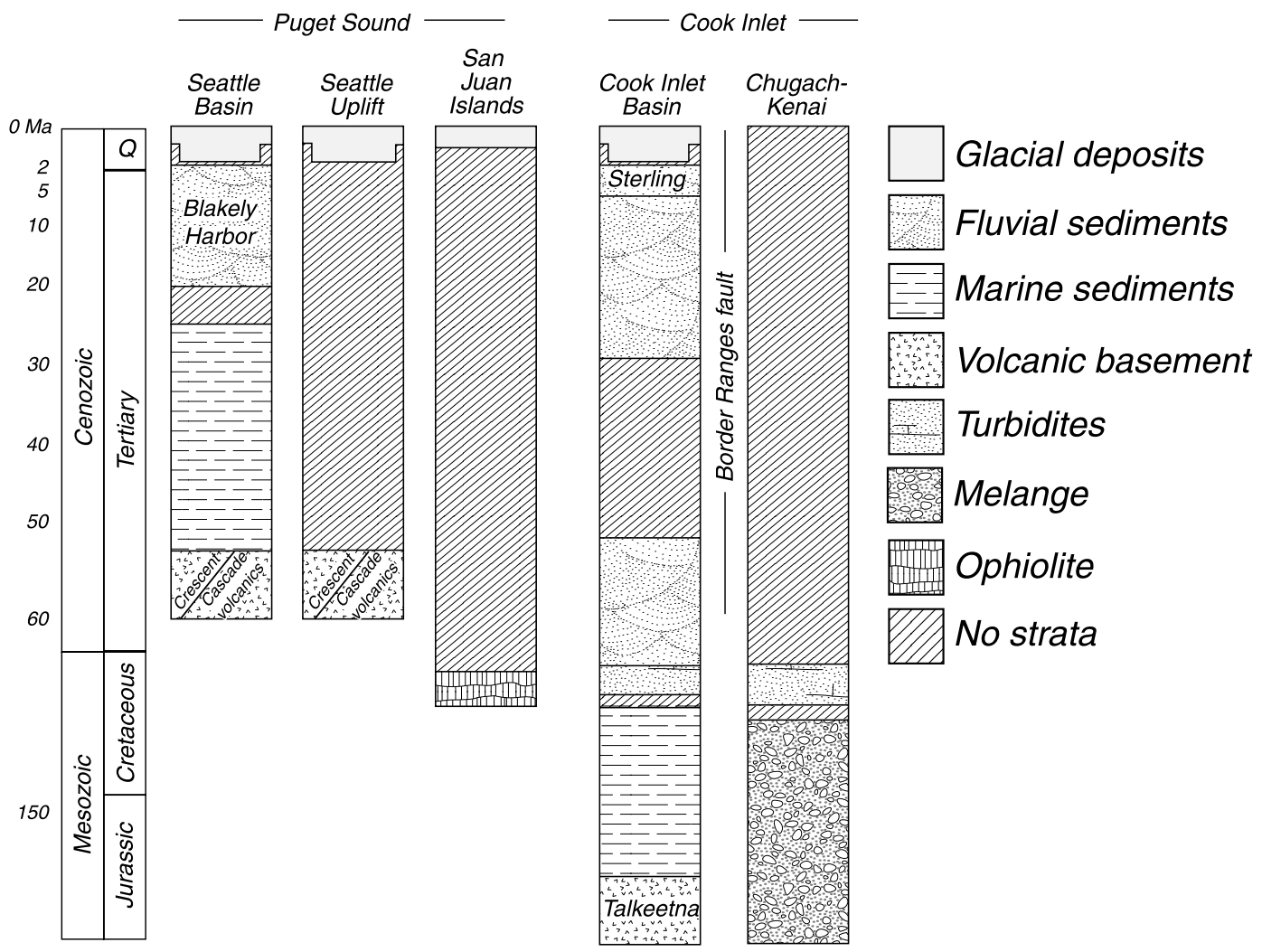

Fig. 4. Comparative stratigraphy for the Puget Sound and Cook Inlet regions. Puget Sound sections simplified from Johnson et al. (1994, 1996). Cook Inlet sections simplified from Magoon et al. (1976) and Magoon and Egbert (1986).

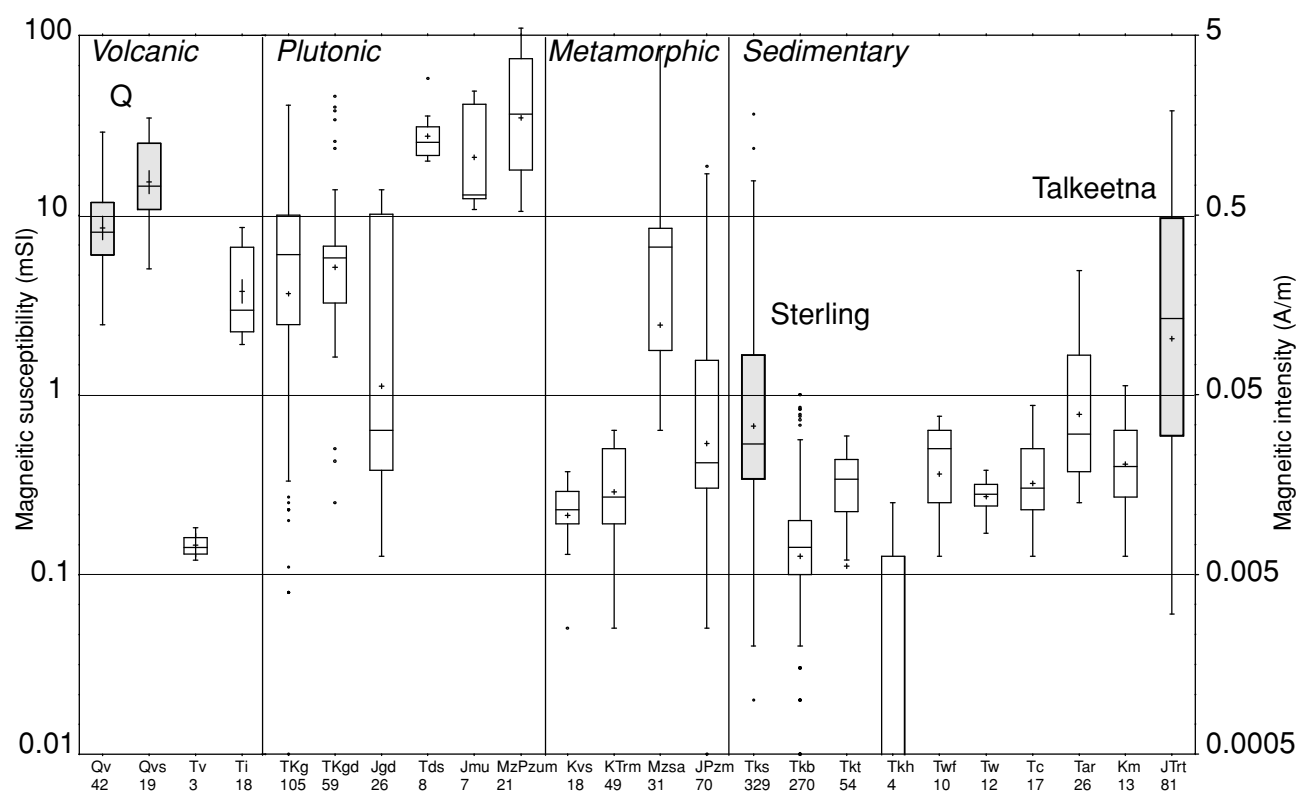

Fig. 5. Box and whisker plot of measured magnetic susceptibilities for geologic units of the Cook Inlet region (Altstatt et al., 2002; Saltus and Haeussler, 2004). Within each box, the central "+" indicates the mean value of the data for that rock formation. Each box depicts values between the 25 th and 75th percentiles. The center bar in each box shows the median value. The whisker ends show the full range of the data, not counting outliers. Small pluses indicate data points identified as outliers because they fall outside a smooth histogram of the data values. Labels on the horizontal axis under each box are abbreviations of the geologic unit name (Altstatt et al., 2002) above the number of measured values for that unit.

appear to be active (Haeussler et al., 2000), and there is one fault, the Castle Mountain fault, that has a history of Holocene offset (Haeussler et al., 2000). The bedrock geology of the basin is obscured by the cover of Quaternary glacial and fluvial deposits and the shallow waters of Cook Inlet.

\section{Magnetic Stratigraphy}

Basin stratigraphy of the Puget Sound and Cook Inlet regions is similar (Fig. 4). Basins in both regions are underlain by volcanic or volcaniclastic basement with overlying Tertiary marine, fluvial, and Quaternary glacial deposits. The volcanic basement produces high-amplitude anomalies 


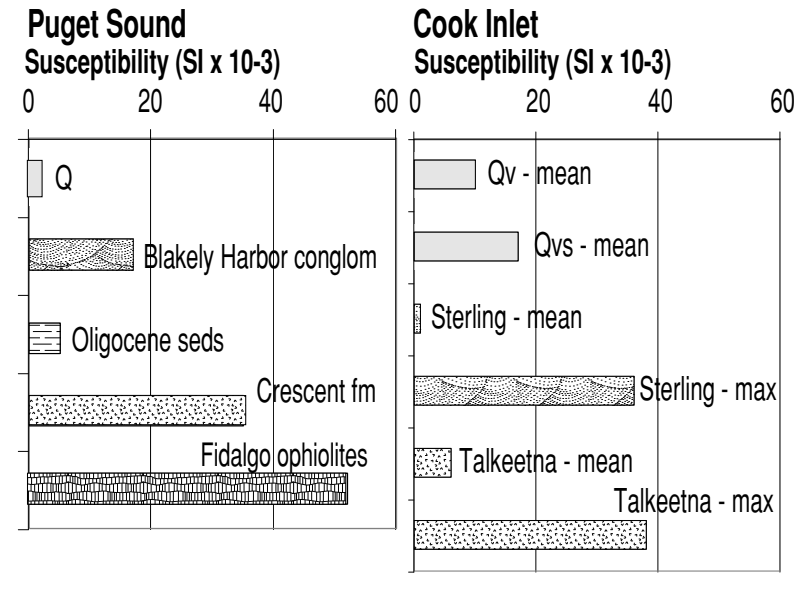

Fig. 6. Comparison between generalized Cook Inlet and Puget Sound magnetic susceptibilities for basinal magnetic source rocks.

with wavelengths characteristic of sources at depth, as observed in aeromagnetic surveys worldwide. Sedimentary rocks are often considered nonmagnetic in other areas, but in the forearc regions of Alaska and Cascadia, late Tertiary and Quaternary deposits contain enough magnetic minerals to sometimes cause low-amplitude, shallow-source aeromagnetic anomalies. Although the deeper, marine portions of the basins are essentially non-magnetic, the shallow Tertiary and Quaternary section contribute to low-amplitude aeromagnetic anomalies.

Measurements of magnetic susceptibility on rocks of the Cook Inlet region (Fig. 5; Altstatt et al., 2002) show that plutonic and volcanic rocks are the primary magnetic sources in the region. Weakly to moderately magnetic sources exist within portions of sedimentary and volcaniclastic units including Quaternary glacial deposits (Saltus and Haeussler, 2004), zones within the predominantly fluvial Tertiary Sterling Formation, and the Triassic to Jurassic Talkeetna Formation.

Similar magnetic relations are observed in the Puget Lowland (Fig. 6), where volcanic bedrock constitutes the dominant magnetic source. Magnetic measurements of Eocene basalts of the Crescent Formation suggest an average susceptibility of $60 \mathrm{mSI}$ (which results in an induced magnetization of 2.75 A/m; Finn, 1990). Overlying Tertiary sediments, on the other hand, are typically very low in magnetization. Susceptibility measurements of upper Eocene to Oligocene Blakeley Formation near Everett, Washington, for example, indicate an average susceptibility of only $0.2 \mathrm{mSI}$ (induced magnetization $0.01 \mathrm{~A} / \mathrm{m}$; Blakely et al., 2004). Exceptions do exist in these Tertiary strata, especially within pebbly layers. A particularly notable example is a basaltic conglomerate that lies within the Miocene Blakely Harbor Formation and is exposed on Bainbridge Island east of Seattle. This conglomerate has a measured susceptibility of $17 \mathrm{mSI}$ (induced magnetization $0.8 \mathrm{~A} / \mathrm{m}$ ) and, because of its steep dip, produces a distinctive, dikelike aeromagnetic anomaly (Blakely et al., 2002). Quaternary glacial deposits are often considered nonmagnetic in other areas, but they can be slightly magnetic in the Puget Lowland. Magnetic susceptibility measurements at five lo- cations between Seattle and Everett indicate susceptibilities ranging from 1 to $2.5 \mathrm{mSI}$ (induced magnetizations of 0.05 to $0.12 \mathrm{~A} / \mathrm{m})$, with an overall average value of $2 \mathrm{mSI}(0.09$ A/m; Blakely et al., 2004).

In both the Cook Inlet and Puget Lowland, shallowsource aeromagnetic anomalies are predicted to arise from structural or topographic features involving surficial or near-surface geologic units. In both regions, Quaternary glacial deposits are sufficiently magnetic to produce shortwavelength magnetic features of $10 \mathrm{~s}$ of $\mathrm{nT}$ (Saltus and Haeussler, 2004). Portions of the fluvial Tertiary section (distinct units within the Blakely Harbor Formation in Puget Sound, as described above, and parts of the Sterling Formation in Cook Inlet) are sufficiently magnetic to produce moderate to large amplitude magnetic anomalies with short to moderate wavelengths. And in both regions the volcanic basement rocks (Crescent Formation in Puget Sound, Talkeetna Formation in Cook Inlet) are highly magnetic and produce long-wavelength anomalies reflecting basement topography, compositional variation, and structural disruption.

\section{Aeromagnetic Data and Analysis}

During the past decade, the U.S. Geological Survey has conducted detailed, moderate- to high-resolution aeromagnetic surveys over both the Puget Sound (Fig. 7; Blakely et al., 1999) and Cook Inlet (Fig. 8; Saltus et al., 2001) regions.

In Puget Sound (Fig. 7), high-amplitude, shortwavelength magnetic highs surround the Everett, Seattle, and Tacoma basins and correspond in some cases to exposures of pre-Tertiary ophiolite, Eocene Crescent Formation and other crystalline basement rocks, and Cascade volcanic rocks. Without exception, all of the known or suspected major fault zones of the Puget Lowland (Fig. 2) are represented by linear magnetic anomalies (Fig. 7). Of particular interest, several distinctive east-west magnetic lineations follow and parallel the Seattle fault zone, known to be responsible for 3 or 4 ground-rupturing earthquakes over the last 2500 years (Nelson et al., 2003).

In Cook Inlet (Fig. 8), high amplitude, short wavelength magnetic highs surround the basins and correspond to exposures of Triassic and younger volcanic and plutonic rocks, including the Talkeetna Formation. Sharp and distinctive magnetic features correspond with, or are parallel to, the mapped trace of the Castle Mountain and Border Ranges faults (Fig. 3). In addition, a variety of subtle short-wavelength features are also present, many with north-northeast/south-southwest trend.

We used matched filtering (Syberg, 1972; Phillips, 1997) to characterize the magnetic fields of the Puget Sound and Cook Inlet regions. This method uses Fourier-domain characteristics of potential fields to estimate depths of principal sources. The resulting filters can then be used to decompose observed magnetic anomalies into estimates of the anomalies caused by sources at those principal depths. A comparison of a five-level decomposition of the aeromagnetic data from each region (Fig. 9) shows remarkably similar wavenumber content and matched-filter depths for both the Puget Sound and Cook Inlet regions. We interpret these 


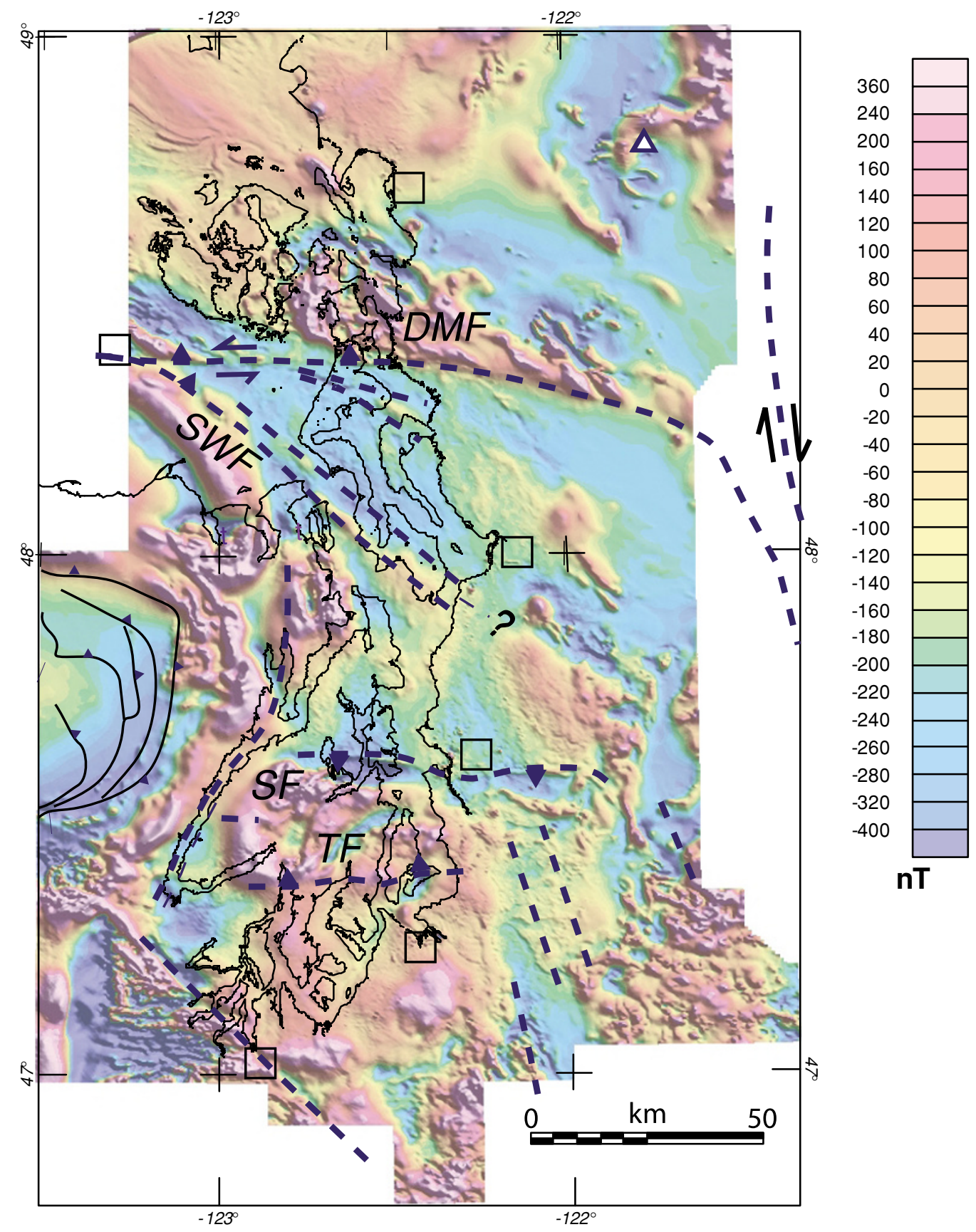

Fig. 7. Total field composite aeromagnetic map of the Puget Sound region (Blakely et al., 1999). Faults (solid and dashed lines) from Fig. 2: DMF, Devils Mountain fault; SWF, southern Whidbey Island fault; and TF, Tacoma fault. Cities (open squares) from Fig. 2.

layers as follows: Half-space filter A represents anomalies arising from sources in and below the pre-Cenozoic basement, thin sheet layer $B$ is the upper portion of the magnetic basement, layers C and D are Tertiary and Quaternary rocks and deposits, and layer E consists of sources near and at the surface, including cultural noise and aliasing. The biggest differences in the matched filters occur in the amplitudes of the $\mathrm{C}$ layers and in both the amplitudes and frequencies of the E layers. Puget Sound anomalies show higher Clayer amplitudes than the Cook Inlet, possibly because of strong magnetic sources observed within the Blakely Harbor formation (Blakely et al., 2002) relative to the somewhat weaker magnetic sources in the Sterling Formation. Greater E-layer amplitudes and lower E-layer wavenum- bers in the Cook Inlet relative to Puget Sound may reflect Quaternary deposits with higher susceptibilities or, alternatively, aliasing caused by a lower flight height relative to the flight-line spacing.

Applying matched filters to the aeromagnetic surveys emphasizes anomalies originating from various depth ranges (Fig. 9). In particular, we were interested in examining and comparing that part of the observed magnetic field that originates from intra-basin sources, namely levels C and D. For Puget Sound, the filtered map (Fig. 10) shows a number of shallow-source lineaments, many of which correlate with known fault zones, including the Devils Mountain, southern Whidbey Island, Seattle, and Tacoma faults. Around the margins of the Puget Sound basins, surficial ex- 


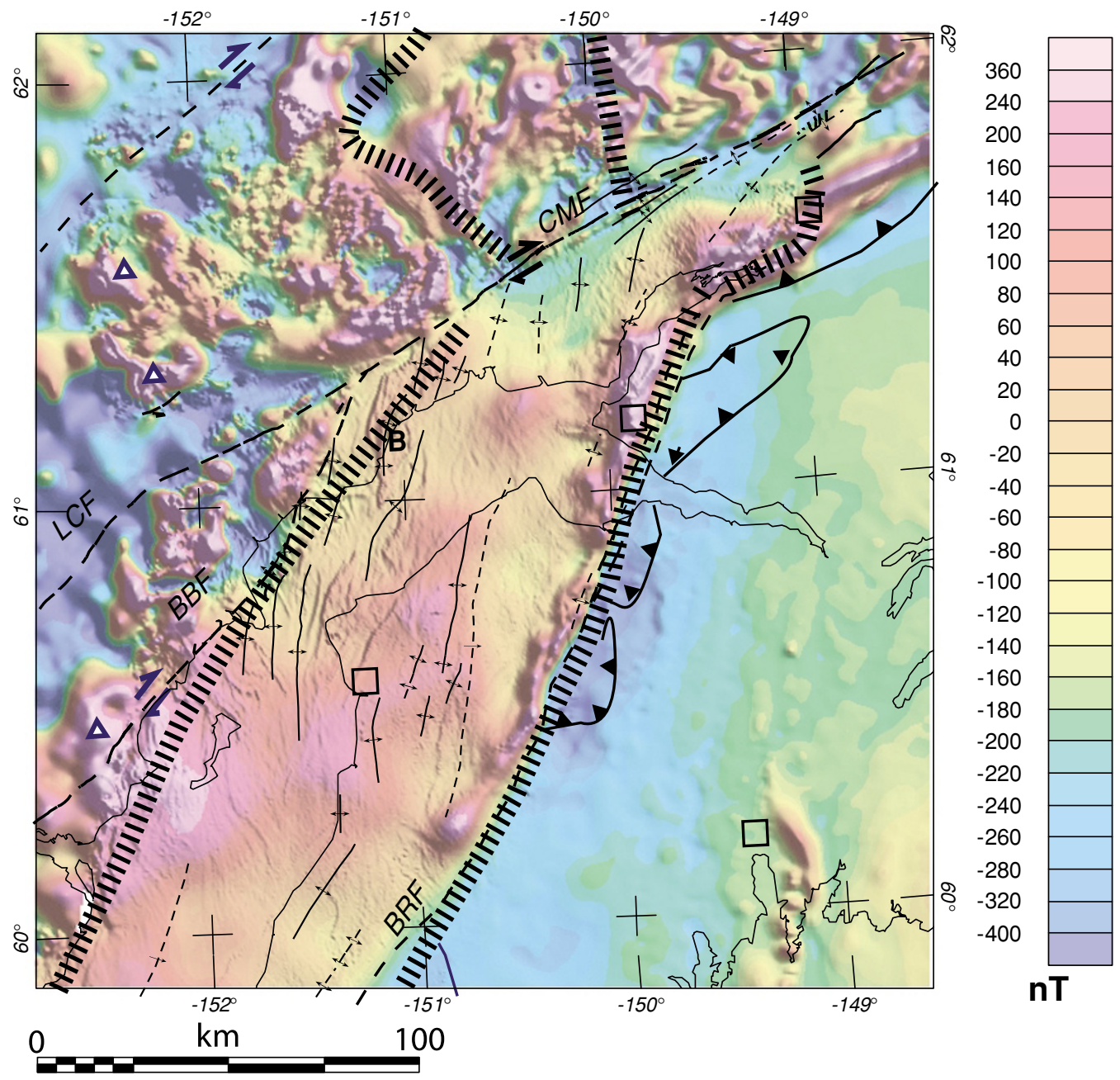

Fig. 8. Total field composite aeromagnetic map of the Cook Inlet region (Saltus et al., 2001). Faults and folds (solid and dashed lines) from Fig. 3: CMF, Castle Mountain fault; LCF, Lake Clark fault; BBF, Bruin Bay fault; and BRF, Border Ranges fault. Cities (open squares) from Fig. 3. Active volcanoes (triangles) from Fig. 3. Beluga Oil and Gas field, B.

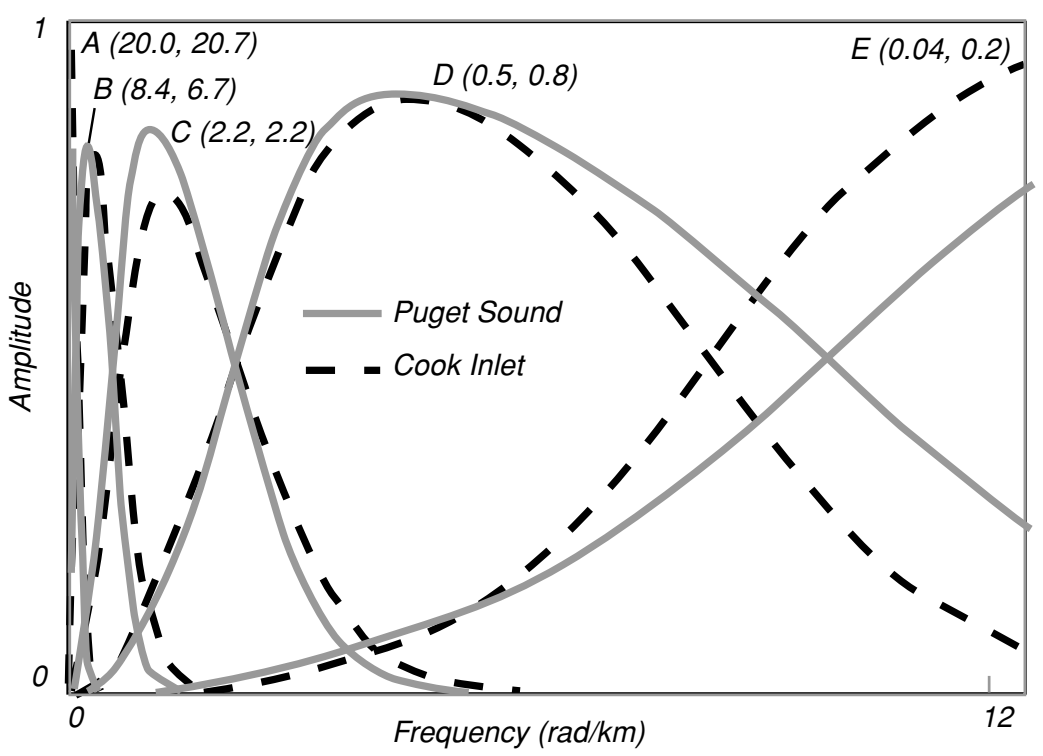

Fig. 9. Matched filter decomposition of total-field aeromagnetic data from the Puget Sound and Cook Inlet regions. In each region the total magnetic field has been separated into 5 components (A-E). The numbers in parentheses are the nominal depth to source (km) for each filter, the first number is for Puget Sound, the second for Cook Inlet. Filter A is for a half-space; all others are thin sheet sources. Filtering depths were determined by visually fitting straight lines to the radial power spectrum of the magnetic anomaly, which were subsequently adjusted via least-squares techniques (Phillips, 1997). 


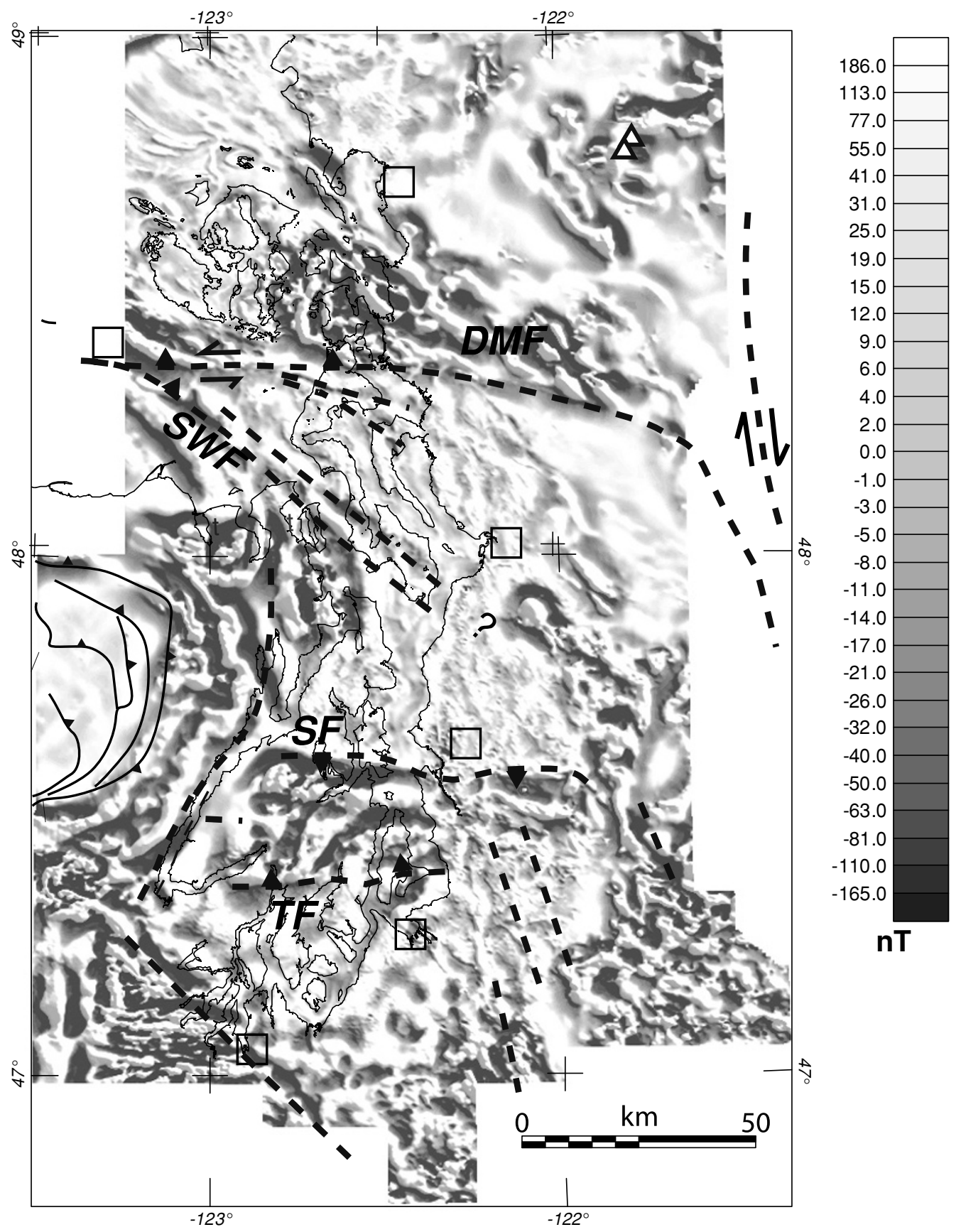

Fig. 10. Shallow bandpass aeromagnetic map of the Puget Sound region. Anomalies nominally represent contributions from layers C and D of Fig. 9 and thus correspond to sources within the upper few kilometers of the crust. Faults (solid and dashed lines) from Fig. 2: DMF, Devils Mountain fault; SWF, southern Whidbey Island fault; and TF, Tacoma fault. Cities (open squares) from Fig. 2.

posures of highly magnetic volcanic rocks cause very intense high/low anomaly pairs. Linear anomalies over the hanging-wall of the Seattle fault correlate one-to-one with sparse exposures of Tertiary volcanic and sedimentary rocks (Blakely et al., 2002). Over the deeper portions of the basins, more subtle anomalies appear, possibly related to internal structure of the basins and local topographic features, such as beach cliffs that lie along the shoreline between Seattle and Everett. Features that trend more or less east-west and northwest-southeast are of particular interest because they may be related to folds and/or faults within the basins.

East-trending linear anomalies along the Seattle fault are compatible with a series of south-side-up thrust faults that offset the Eocene Crescent Formation (Fig. 11; Blakely et al., 2002), consistent with seismic-reflection interpretations (Pratt et al., 1997; Johnson et al., 1994). The same magnetic anomalies are also consistent with a more recent model for the Seattle uplift (Brocher et al., 2004) that includes significant backthrusting, consistent with seismic-reflection, seismic-velocity, and paleoseismic evidence. Any model of the Seattle fault must contend with the Blakely Harbor Formation, a Miocene fluvial section that includes a significantly magnetic basalt conglomerate (Blakely et al., 2002). This steeply dipping conglomerate produces a dike-like magnetic anomaly (the northern high in Fig. 11), shorter 


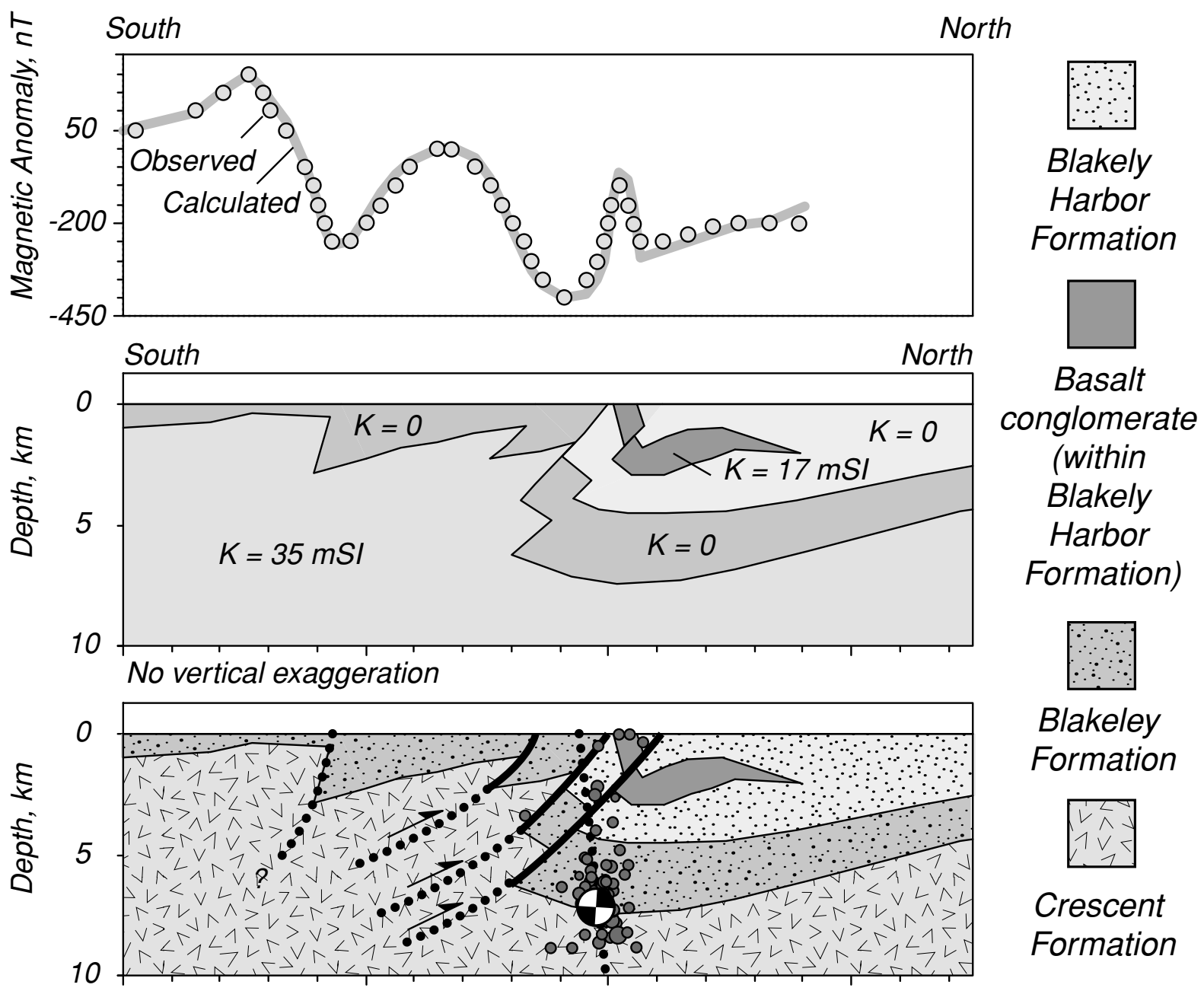

Fig. 11. Detailed, two-dimensional magnetic model across the Seattle fault, Puget Sound, Washington (Blakely et al., 2002).

in wavelength but similar in amplitude to the southern magnetic highs caused by Eocene basalt of the Crescent Formation. Detailed analysis of this conglomerate, incorporating magnetic modeling with constraints from seismic data and geologic mapping, allows us to identify similar rocks along the entire length of the Seattle fault (Blakely et al., 2002).

For Cook Inlet, the bandpass map (Fig. 12) shows a number of similar shallow-source anomalies, including many linear features with trends more or less parallel to the long axis of the Cook Inlet basin. Some of these features, such as the distinctive set of curvilinear features surrounding a magnetic low in the Beluga oil and gas field region, are clearly related to shallow structure seen in seismic data (Haeussler et al., 2000; Saltus et al., 2001; Haeussler and Saltus, in review (a)). Other linear trends, such as those located further to the east over the Kenai Peninsula, may relate to monoclines or other structural or stratigraphic features. The Quaternary glacial deposits in the Cook Inlet region are sufficiently magnetic to generate subtle magnetic anomalies at beach cliffs and other topographic features (Saltus and Haeussler, 2004). Also, sharp-edged linear features extending generally northwest from the active volcanic region of the Aleutian Range are probably related to volcanic and/or volcaniclastic flows (Haeussler and Saltus, in review (b)).

Relative to the Puget Sound, the Cook Inlet has less pub- licly available shallow seismic data and fewer detailed mapping constraints, posing problems for detailed interpretation of shallow-source aeromagnetic anomalies. Regional seismic lines, donated to the USGS by ARCO (and discussed in Haeussler et al., 2000), provide some constraints for potential-field modeling, although these seismic data are not ideally suited for interpretation of shallow detail. In the region of the Beluga oil and gas field, the pattern of seismic reflectors in the flanking syncline can be used to guide the geometry of a consistent model in which discrete magnetic layers within the younger Sterling and/or overlying Quaternary section cause the shallow magnetic features (Fig. 13).

\section{Discussion}

Previous studies have discussed the significance of large aeromagnetic anomalies in subduction/active arc settings including the Pacific Northwest (e.g., Finn, 1990; Wells et al., 1998) and southern Alaska (Grantz et al., 1963; Griscom and Case, 1983). These earlier studies utilized aeromagnetic data collected typically at altitudes greater than $1000 \mathrm{ft}(305 \mathrm{~m})$ and with line spacing of 1 mile or greater (1600 m or greater). Because of the mathematical fall off of sensitivity to shallow sources, in addition to older, lower resolution instrumentation and less accurate navigation, these earlier aeromagnetic surveys were primarily sen- 


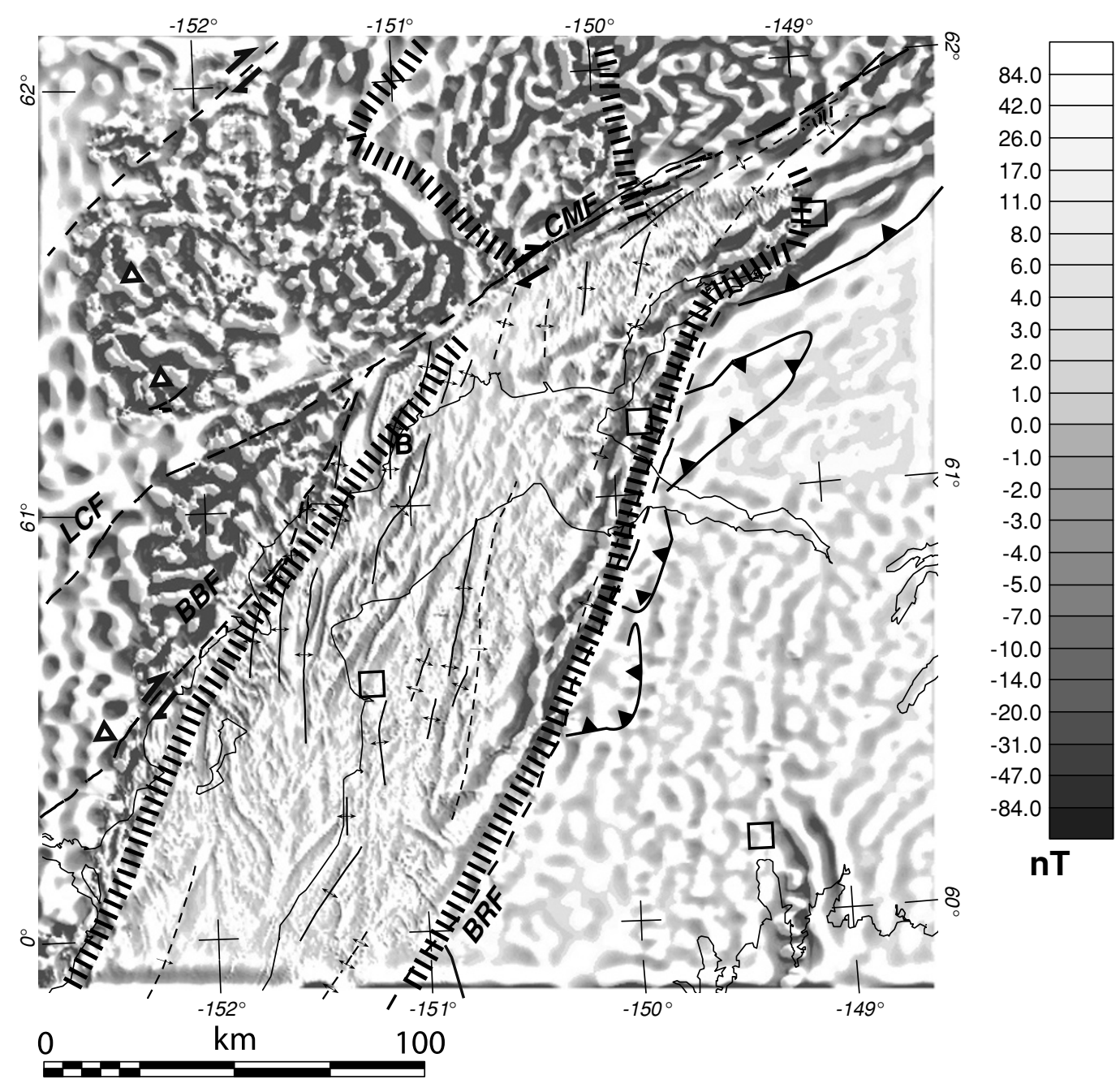

Fig. 12. Shallow bandpass aeromagnetic map of the Cook Inlet region. Anomalies nominally represent contributions from layers C and D of Fig. 9 and thus correspond to sources within the upper few kilometers of the crust. Faults and folds (solid and dashed lines) from Fig. 3: CMF, Castle Mountain fault; LCF, Lake Clark fault; BBF, Bruin Bay fault; and BRF, Border Ranges fault. Cities (open squares) from Fig. 3. Active volcanoes (triangles) from Fig. 3. Beluga Oil and Gas field, B.

sitive to and interpreted in terms of thick, regional magnetic sources such as crystalline basement and regional extrusive and/or intrusive volcanic or plutonic complexes.

Advances in measurement and navigation technology, improved data processing, and new interpretation methods have given us the ability to investigate more subtle magnetic sources, particularly those arising within sedimentary basins (e.g., Grauch, 2001). High-resolution aeromagnetic surveys (flight heights as low as $100 \mathrm{ft}-30.5 \mathrm{~m}$, and line spacing as narrow as $1 / 8$ mile-200 m) show a wealth of anomaly detail not present in pre-1980's data.

Although improved data acquisition and processing have sharpened our view of the low-altitude magnetic field, magnetic surveys are still subject to the fundamental nonuniqueness of potential-field interpretation. In one sense, interpretation has become more difficult. We no longer can make the blanket assumption (as was often done in older studies) that sedimentary rocks are nonmagnetic. We are now using aeromagnetic data to investigate a wider range of crustal depths than ever before, and it is increasingly important to incorporate independent information, such as detailed magnetic property measurements and depth con- straints from boreholes or other geophysical methods, in order to reasonably limit the range of permissible Earth models.

Aeromagnetic studies have led to speculation (Blakely et al., 2005), consistent with deep seismic interpretation (Bostock et al., 2002; Brocher et al., 2003), that a portion of the longest-wavelength aeromagnetic anomalies over the Cascadia forearc originate from serpentinization of the mantle wedge above the subducting slab. If correct, this interpretation extends the bottom of the potentially magnetic layer to beneath the continental Moho of the Cascadia forearc and to depths greater than $50 \mathrm{~km}$. It has also been proposed that a similar deep source may contribute to long-wavelength components of the southern Alaska magnetic high (Blakely et al., 2005).

While it is reasonable to postulate the contribution of deep serpentinized mantle to the total aeromagnetic signature in both Puget Sound and Cook Inlet, it is evident that long-wavelength anomalies arise mainly from mid- to upper-crustal sources, namely magnetic basement and intrusive rocks related to the arc settings discussed above. In addition, it is clear that portions of the basin sedimentary 


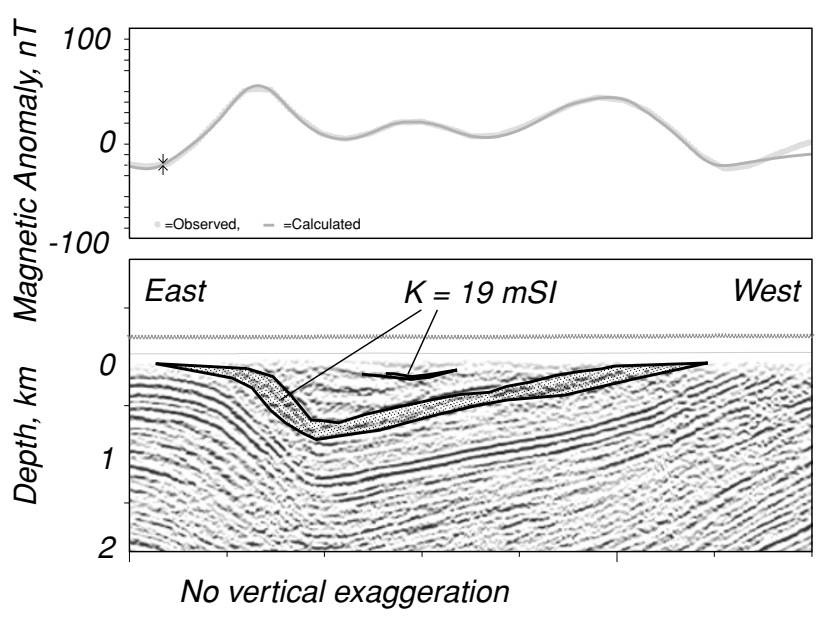

Fig. 13. Detailed, two-dimensional magnetic model over the Beluga structure, Cook Inlet, Alaska. Seismic data from Haeussler et al. (2000).

section and, indeed even surficial deposits, are sufficiently magnetic to produce weak-to-moderate amplitude aeromagnetic anomalies as well.

Interpretation of broad (long-wavelength) anomalies has the greatest theoretical ambiguity. The short-wavelength content of a magnetic anomaly is limited by the depth to its source. While shallow sources can produce both long- and short-wavelength anomalies, depending on the wavenumber content of the shallow source, deep sources produce only anomalies with characteristically long wavelengths, regardless of the wavenumber content of sources. It is not possible, therefore to distinguish shallow from deep sources using long-wavelength magnetic anomalies alone. These limitations must be kept in mind when estimating magnetic depth, as attempted here with the matched filtering technique. The matched-filter results for Puget Sound and Cook Inlet (Fig. 9) indicate similar wavenumber content in the two aeromagnetic surveys, but they do not strictly prove that the magnetic sources are concentrated at the depths indicated. In the case of each bandpass filter, some or all of the source energy in that band could arise from a shallower level. However, in both Puget Sound and Cook Inlet it is geologically reasonable to expect magnetic sources at a range of depths, so the results are not surprising.

In both Puget Sound and Cook Inlet, we have constrained our interpretations with seismic and gravity data where available. Puget Sound has better published seismic coverage than Cook Inlet, particularly for the deeper crust. Regional gravity data are available in both regions. In Puget Sound, Brocher et al. (2003) found isostatic residual gravity anomalies to be consistent with densities calculated from three-dimensional seismic models using Gardner's relation (Gardner et al., 1974). In Cook Inlet, isostatic gravity anomalies are too low in amplitude to be caused solely by the known thickness of sediments in the Cook Inlet basin, and it is clear that the region is not in local isostatic balance (Barnes, 1977). The crust beneath sea-level elevations in Cook Inlet probably exceeds $50 \mathrm{~km}$ in thickness. Thus the standard local (Airy) isostatic model is not useful here for predicting and removing the effects of deep crustal gravity sources in order to isolate the gravity expression of the basin itself. Independent Moho-depth determinations (i.e. from deep seismic or electrical soundings) would aid in this endeavor. Failing that determination, wavelength filtering can be used to produce an estimated basin gravity map.

Interpretation of short-wavelength aeromagnetic features is considerably less problematic, as these anomalies cannot originate from great depths. Thus, shallow bandpass and highpass filters derived from matched filtering (Puget Sound, Fig. 10; Cook Inlet, Fig. 12) or upward-continuation residuals (e.g., Blakely et al., 2002) are reliable indicators of patterns related to the distribution of shallow magnetic sources.

In addition to understanding seismic hazards, knowledge of shallow structure is important for hydrocarbon exploration. Puget Sound has no known hydrocarbon potential, but Cook Inlet hosts significant oil and gas resources (Kirschner and Lyon, 1973; Magoon et al., 1976; Magoon, 1994) and is still being developed (Anonymous, 1999). Although the initial hydrocarbon discovery and much of the exploration in Cook Inlet preceded collection of aeromagnetic data in the region, the correspondence of linear shortwavelength aeromagnetic features with known folds (e.g., Fig. 12), many of which host hydrocarbons, demonstrates the utility of high-resolution aeromagnetic surveys as an exploration tool, particularly for early work in a frontier area. Regional aeromagnetic reconnaissance is much more economical than seismic data collection and exploratory drilling. In a well-developed region, detailed aeromagnetic data can assist in mapping out the full extent of known structures.

\section{Conclusions}

Aeromagnetic anomalies from the Puget Sound and Cook Inlet regions show remarkable similarity in wavenumber and amplitude. In particular, the aeromagnetic data from both regions contain a rich array of shallow-source features related to faults and folds and thus important for seismichazard assessment. Magnetic properties of the stratigraphic sections are also similar: Pre-Cenozoic and Eocene volcanic basement is significantly magnetic, deep basin sediments of Tertiary age and marine origin are generally nonmagnetic, and shallower Tertiary fluvial and Quaternary glacial deposits are sufficiently magnetic to produce smallamplitude anomalies. In both Puget Sound and Cook Inlet, matched filtering of the aeromagnetic data yields bandpass and highpass aeromagnetic maps that delineate these shallow features. Based on our results in these two regions, it appears likely that other forearc basins will show the same kinds of aeromagnetic features. Therefore, aeromagnetic data are expected to provide a useful aid in mapping the location and extent of shallow faults and folds that may be important for understanding of the seismic hazards, possible resource potential, and structural framework of other forearc basins.

Acknowledgments. This paper was presented at the 2003 International Union of Geodesy and Geophysics (IUGG) meeting in Sapporo, Japan. The authors thank Gerry Connard and Tom Pratt for careful reviews and useful comments on the first draft of the paper. Bob Jachens and Sam Johnson provided constructive reviews of the final manuscript. 


\section{References}

Altstatt, A. A., R. W. Saltus, R. L. Bruhn, and P. J. Haeussler, Magnetic susceptibilities measured on rocks of the upper Cook Inlet, Alaska, U.S. Geological Survey Open-File Report 02-0139, 17 pp., [http://pubs.usgs.gov/of/2002/ofr-02-0139], 2002.

Anonymous, Cook Inlet basin still holds some exploration, development allure, Oil and Gas Journal, 99(10), 43, 1999.

Atwater, B. F. and E. Hemphill-Haley, Recurrence intervals for great earthquakes of the past 3500 years at northeastern Willapa Bay, Washington, U.S. Geological Survey Professional Paper 1576, 108 pp., 1997.

Barnes, D. F., Bouguer gravity map of Alaska, U.S. Geological Survey Map GP-913, scale 1:2,500,000, 1 sheet., 1977.

Blakely, R. J., R. E. Wells, and C. S. Weaver, Puget Sound aeromagnetic maps and data, U.S. Geological Survey Open-File Report 99-514, http://geopubs.wr.usgs.gov/open-file/of99-514, 1999.

Blakely, R. J., R. E. Wells, C. S. Weaver, and S. Y. Johnson, Location, structure, and seismicity of the Seattle fault zone, Washington: Evidence from aeromagnetic anomalies, geologic mapping, and seismic-reflection data, Geological Society of America Bulletin, 114, 169-177, 2002.

Blakely, R. J., T. M. Brocher, and R. E. Wells, Subduction zone magnetic anomalies and implications for hydrated forearc mantle, Geology, 33, 445-448, 2005.

Blakely, R. J., B. L. Sherrod, R. E. Wells, C. S. Weaver, D. H. McCormack, K. G. Troost, and R. A. Haugerud, The Cottage Lake aeromagnetic lineament: A possible onshore extension of the southern Whidbey Island fault, Washington, U.S. Geological Survey Open-File Report 2004-1204, $61 \mathrm{pp}$.

Bostock, M. G., R. D. Hyndman, S. Rondenay, and S. M. Peacock, An inverted continental Moho and serpentinization of the forearc mantle, Nature, 417, 536-538, 2002.

Brocher, T. M., R. J. Parsons, R. J. Blakely, N. I. Christensen, M. A. Fisher, R. E. Wells, and the SHIPS Working Group, Upper crustal structure in Puget Lowland, Washington: Results from the 1998 Seismic Hazards Investigation in Puget Sound, Journal of Geophysical Research, 106, 13,541-13,564, 2001.

Brocher, T. M., T. Parsons, A. M. Tréhu, C. M. Snelson, and M. A. Fisher, Seismic evidence for widespread serpentinized forearc upper mantle along the Cascadia margin, Geology, 31, 267-270, 2003.

Brocher, T. M., R. J. Blakely, and R. E. Wells, Interpretation of the Seattle Uplift, Washington, as a passive roof duplex, Bulletin of the Seismological Society of America, 94(4), 1379-1401, 2004.

Bucknam, R. C., E. Hemphill-Halley, and E. B. Leopold, Abrupt uplift within the past $1700 \mathrm{yr}$ at southern Puget Sound, Washington, Science, 258, 1611-1614, 1992.

Christensen, D. H. and S. L. Beck, The rupture process and tectonic implications of the great 1964 Prince William Sound earthquake, Pure and Applied Geophysics, 142, 29-53, 1994.

Combellick, R. A., Paleoseismicity of the Cook Inlet region, Alaska: Evidence from peat stratigraphy in Turnagain and Knik Arms, Alaska Division of Geological and Geophysical Surveys Professional Report 112, 52 pp., 1991

Combellick, R. A., The penultimate great earthquake in southcentral Alaska: Evidence from a buried forest near Girdwood, Short notes on Alaskan geology 1993, edited by D. N. Solie and F. Tannian, Alaska Division of Geological and Geophysical Surveys Professional Report 113, pp. 7-15, 1993

Combellick, R. A., Investigations of peat stratigraphy in tidal marshes along Cook Inlet, Alaska, to determine the frequency of 1964-style great earthquakes in the Anchorage region, Alaska Division of Geological and Geophysical Surveys Report of Investigations 94-7, 24 pp., 1994.

Finn, C., Geophysical constraints on Washington convergent margin structure, Journal of Geophysical Research, 95, 19,533-19,546, 1990.

Frankel, A. D., D. L. Carver, and R. A. Williams, Nonlinear and linear site response and basin effects in Seattle for the M 6.8 Nisqually, Washington, earthquake, Bulletin of the Seismological Society of America, 92, 2090-2109, 2002.

Gardner, G. H. F., L. W. Gardner, and A. R. Gregory, Formation velocity and density: the diagnostic basics for stratigraphic traps, Geophysics, 39, 770-780, 1974

Grantz, A., I. Zeitz, and G. E. Andreasen, An Aeromagnetic Reconnaissance of the Cook Inlet Area Alaska, U.S. Geological Survey Professional Paper 316-G, pp. 117-134, 1963.

Grauch, V. J. S., High-resolution aeromagnetic data, a new tool for mapping intrabasinal faults: Example from the Albuquerque basin, New Mexico, Geology, 29, 367-370, 2001.
Griscom, A. and J. E. Case, Magnetic expression of geologic terranes in southern Alaska, Geophysics, 48, 444-445, 1983.

Haeussler, P. J. and R. W. Saltus, Location, extent, and estimates of deformation rates of Tertiary structures in the Cook Inlet basin, Alaska, U.S. Geological Survey Open-File Report 04-XXX, XX pp., [http://pubs.usgs.gov/of/2004/ofr-04-XXX/], in review (a).

Haeussler, P. J. and R. W. Saltus, Lahars as aeromagnetic anomaly sources, Cook Inlet, Alaska, U.S. Geological Survey Open-File Report, in review (b).

Haeussler, P. J., R. L. Bruhn, and T. L. Pratt, Potential seismic hazards and tectonics of the upper Cook Inlet basin, Alaska, based on analysis of Pliocene and younger deformation, Geological Society of America Bulletin, 112(9), 1414-1429, 2000.

Hyndman, R. D. and K. Wang, The rupture zone of Cascadia great earthquakes from current deformation and the thermal regime, Journal of Geophysical Research, 100, 22,133-22,154, 1995.

Johnson, S. Y., C. J. Potter, and J. M. Armentrout, Origin and evolution of the Seattle fault and Seattle basin, Washington, Geology, 22, 71-74, 1994.

Johnson, S. Y., C. J. Potter, J. M. Armentrout, J. J. Miller, C. Finn, and C. S. Weaver, The southern Whidbey Island fault: An active structure in the Puget lowland, Washington, Geological Society of America Bulletin, 108, 334-354, 1996.

Kirby, S., E. R. Engdahl, and R. Denlinger, Intermediate-depth intraslab earthquakes and arc volcanism as physical expressions of crustal and uppermost mantle metamorphism in subducting slabs, in Subduction: Top to Bottom, edited by G. E. Bebout et al., pp. 195-214, American Geophysical Union Monograph 96, 1996.

Kirschner, C. E. and C. A. Lyon, Stratigraphic and tectonic development of Cook Inlet petroleum province, in Arctic Geology, pp. 396-407, American Association of Petroleum Geologists Memoir 19, 1973.

Magoon, L. B., Petroleum resources in Alaska, in The Geology of Alaska, The Geology of America, edited by G. Plafker and H. C. Berg, v. G-1, pp. 905-936, Geological Society of America, 1994.

Magoon, L. B. and R. M. Egbert, Framework geology and sandstone composition, Geologic studies of the lower Cook Inlet COST No. 1 well, Alaska outer continental shelf, edited by L. B. Magoon, U.S. Geological Survey Bulletin, 1596, 65-90, 1986.

Magoon, L. B., W. L. Adkison, and R. M. Egbert, Map showing geology, wildcat wells, Tertiary plant fossil localities, K-Ar age dates, and petroleum operations, Cook Inlet area, Alaska, U.S. Geological Survey Map I-1019, scale 1:250,000, 3 sheets, 1976.

Nelson, A. R., S. Y. Johnson, H. M. Kelsey, R. E. Wells, B. L. Sherrod, S. K. Pezzopane, L. A. Bradley, R. D. Koehler, III, and R. C. Bucknam, Late Holocene earthquakes on the Toe Jam Hill fault, Seattle fault zone, Bainbridge Island, Washington, Geological Society of America Bulletin, 115, 1388-1403, 2003.

Phillips, J. D., Potential-field geophysical software for the PC-version 2.2, U.S. Geological Survey Open-File Report 97-725, 34 pp. [http:// pubs.usgs.gov/of/1997/ofr-97-0725/], 1997.

Plafker, G., Tectonic deformation associated with the 1964 Alaska earthquake, Science, 148, 1675-1687, 1965.

Pratt, T. L., S. Johnson, C. Potter, W. Stephenson, and C. Finn, Seismic reflection images beneath Puget Sound, western Washington State: The Puget Lowland thrust sheet hypothesis, Journal of Geophysical Research, 102, 27,469-27,489, 1997.

Saltus, R. W. and P. J. Haeussler, Magnetic properties of Quaternary deposits, Kenai Peninsula, Alaska-Implications for aeromagnetic anomalies in upper Cook Inlet, U.S. Geological Survey Open-File Report 2004-1202, 26 pp., [http://pubs.usgs.gov/of/2004/ofr-2004-1202], 2004.

Saltus, R. W., P. J. Haeussler, R. E. Bracken, J. P. Doucette, and R. C. Jachens, Anchorage Urban Region Aeromagnetics (AURA) ProjectPreliminary Geophysical Results, U.S. Geological Survey Open-File Report 01-0085, 21 pp., [http://pubs.usgs.gov/of/2001/ofr-01-0085/], 2001.

Syberg, F. J. R., A Fourier method for the regional-residual problem of potential fields, Geophysical Prospecting, 20, 47-75, 1972.

Wells, R. E., C. S. Weaver, and R. J. Blakely, Fore-arc migration in Cascadia and its neotectonic significance, Geology, 26, 759-762, 1998.

R. W. Saltus (e-mail: saltus@usgs.gov), R. J. Blakely, P. J. Haeussler, and R. E. Wells 